\title{
INCREASING CHILDREN'S ENGLISH ABILITY THROUGH READING WORD MEDIA ANDROID-BASED IN OASIS KIDS NATIONAL PLUS SCHOOL GROUP B ACADEMIC YEAR 2018/2019
}

\author{
Anjar Fitrianingtyas ${ }^{1)}$, Jumiatmoko ${ }^{2)}$, Nurul Shofiatin Zuhro ${ }^{3)}$ \\ PG PAUD FKIP Universitas Sebelas Maret \\ anjarfitrianingtyas@staff.uns.ac.id
}

\begin{abstract}
This research is a Class Action Research which aims to improve English ability of group B consist of 7 children. This research was conducted in two cycles and each cycle consist of five stages that are planning, implementing actions, observing and reflecting. Data collection method used observation, interview and documentation. Data analysis technique used qualitative descriptive technique. The results showed the achievement of indicators and an increase in English ability. It can be seen from the pre-cycle English ability in the good category of $14.28 \%$, then in the first cycle increased to $21.43 \%$ and in the second cycle the English ability of children increased by $75 \%$. The conclusion of this research is that through the reading word media android-based can improve English ability of children in Oasis Kids National Plus School in Group B academic year 2018/2019. There is a suggestion for educators to try improving children's English ability by using a variety of learning media, one of which is to use reading word media android-based. In addition, a suggestion for schools is to be a place for early childhood education to be able to provide learning activities in accordance with the characteristics of children's learning abilities.
\end{abstract}

Keywords: reading word media, English ability

MENINGKATKAN KEMAMPUAN BERBAHASA INGGRIS ANAK MELALUI MEDIA BACA KATA BERBASIS ANDROID PADA PESERTA DIDIK KELOMPOK B PAUD OASIS KIDS NATIONAL PLUS SCHOOL TAHUN AJARAN 2018/2019

Abstrak: Penelitian ini berupa Penelitian Tindakan Kelas yang bertujuan untuk meningkatkan kemampuan berbahasa Inggris anak kelompok B dengan jumlah 7 anak. Penelitian ini dilaksanakan dalam dua siklus dan setiap siklus melalui 5 tahapan yaitu perencanaan, pelaksanaan tindakan, observasi dan refleksi. Metode pengumpulan data menggunakan observasi, wawancara dan dokumentasi. Teknik analisis data menggunakan teknik deskriptif kualitatif. Hasil penelitian menunjukkan tercapainya indikator keberhasilan penelitian tindakan kelas dan adanya peningkatan kemampuan berbahasa Inggris. Dapat dilihat dari kemampuan berbahasa Inggris pra siklus pada kategori baik sebesar $14.28 \%$, kemudian pada siklus I meningkat menjadi $21.43 \%$ dan pada siklus II kemampuan berbahasa Inggris anak meningkat sebesar $75 \%$. Kesimpulan penelitian ini adalah bahwa melalui media baca kata berbasis android dapat meningkatkan kemampuan berbahasa Inggris anak kelompok B PAUD Oasis Kids Semarang tahun ajaran 2018/2019. Saran bagi pendidik agar berupaya meningkatkan kemampuan Bahasa Inggris dengan menggunakan media pembelajaran yang lebih beragam, salah satunya adalah dengan menggunakan media Baca Kata berbasis android. Bagi sekolah agar menjadi wadah berlangsungnya pendidikan anak usia dini yang mampu memberikan kegiatan pembelajaran yang sesuai dengan karakteristik kemampuan belajar anak.

Kata Kunci: media baca kata, kemampuan berbahasa Inggris

\section{PENDAHULUAN}

Dalam era globalisasi ini, pemerintah menyadari pentingnya peran
Bahasa Inggris dan sumber daya manusia yang memiliki keandalan berkomunikasi dalam bahasa Inggris, 
yang di Indonesia merupakan bahasa asing. Sebagai kebijakan yang berorientasi ke depan, pemerintah telah menerbitkan Undang-Undang Republik Indonesia nomor 2 Tahun 1989 tentang Sistem Pendidikan Nasional diikuti dengan Peraturan Pemerintah Nomor 28 Tahun 1990 yang menyebutkan tentang pengembangan sumber daya manusia. Pengembangan sumber daya manusia dalam dunia pendidikan antara lain dalam bentuk pengembangan dan peningkatan kualitas kemampuan dan keterampilan guru, siswa, dan tenaga kependidikan yang terkait.

Bahasa Inggris sebagai salah satu bahasa asing di Indonesia mulai dimungkinkan untuk diajarkan lebih dini sebagai mata pelajaran muatan lokal berdasarkan Surat Keputusan Menteri Pendidikan dan Kebudayaan Nomor 060/U/1993 tanggal 25 Februari 1993. Sesuai dengan anjuran pemerintah mata pelajaran tersebut dapat dimulai di kelas 4 SD. Namun pada kenyataannya di lapangan, banyak sekolah dasar terutama sekolah dasar swasta yang mulai mengajarkan bahasa Inggris sejak kelas $1 \mathrm{SD}$.

Oasis Kids National Plus School sebagai lembaga pendidikan anak usia dini yang menerapkan sistem bilingual dalam kegiatan belajar mengajar sudah mulai untuk menerapkan dan mengajarkan bahasa Inggris sejak usia toddler, playgroup dan kindergarten yaitu sejak usia 2 tahun sampai usia 6 tahun dalam kegiatan harian. Hal-hal yang mendukung anak untuk belajar bahasa asing sejak dini yaitu pertama, anak usia dini memiliki pendengaran dan memori yang tajam. Mereka dapat belajar mengikuti bunyi dengan cepat dan tepat serta dapat menguasai pembelajaran baru tanpa kesulitan. Kedua, anak-anak memiliki hambatan yang lebih sedikit, merespon dengan senang dan spontan.

Pendidikan anak usia dini merupakan suatu upaya pembinaan yang ditujukan kepada anak sejak lahir sampai dengan usia 6 tahun yang dilakukan melalui pemberian rangsangan pendidikan untuk membantu pertumbuhan dan perkembangan jasmani dan rokhani agar anak memilki kesiapan dalam memasuki pendidikan lebih lanjut. (pasal 1 ayat 14 Undang-undang Nomor 20 Tahun 2003). Sejalan dengan pengertian tersebut, maka Oasis Kids National Plus School berusaha untuk memberikan stimulasi sejak dini kepada anak-anak untuk belajar bahasa Inggris melalui pembiasaan agar kelak ketika memasuki pendidikan dasar anakanak lebih siap untuk menerima pembelajaran bahasa Inggris dengan materi yang lebih lanjut.

Pada jenjang TK B yaitu anak usia 5-6 tahun diharapkan penguasaan kosakata (vocabulary) pada anak lebih banyak dibandingkan dengan anak usia dibawah 5 tahun. Selama ini telah berbagai macam upaya dilakukan untuk memperkaya kosakata bahasa Inggris anak-anak Oasis Kids khususnya pada anak TK B. Upaya yang telah dilakukan yaitu dengan mengajarkan anak-anak lagu berbahasa Inggris sesuai dengan tema dan menggunakan flashcard untuk memperkenalkan kosakata baru pada anak. Namun, hal tersebut dirasa kurang maksimal untuk memperkaya kosakata anak. Karena selama ini lebih dominan guru yang menguasai jalannya kegiatan belajar mengajar bahasa Inggris. Contoh konkretnya yaitu ketika menggunakan flashcard guru menunjukkan flashcard tersebut kepada anak-anak kemudian menyebutkan gambar yang dimaksud dan anak-anak hanya menirukan kata yang diucapkan oleh sang guru. Sehingga anak masih cenderung belajar secara pasif dan kemampuan berbahasa Inggris yang dikuasai anak belum maksimal. 
Sedangkan menurut Piaget (1969, dalam Suyanto, 2007:6) [1], semua anak adalah pebelajar aktif. Pengetahuan yang diperoleh dari tindakannya merupakan pengetahuan yang dikembangkan sendiri, bukan sekadar menirukan atau memang sudah dimiliki. Pengetahuan baru merupakan pengetahuan yang secara aktif disusun oleh anak itu sendiri. Merujuk teori tersebut, maka peneliti berupaya untuk menemukan suatu alternatif pembelajaran bahasa Inggris di PAUD Oasis Kids yaitu dengan menggunakan media pembelajaran audio visual berbasis android yang peneliti beri nama media baca kata.

Media baca kata merupakan suatu media pembelajaran audio visual yang menggunakan tekhnologi informatika berupa tablet atau ipad berbasis android dalam pengoperasiannya. Sebuah aplikasi sederhana yang mudah digunakan oleh anak. Dengan media tersebut anak akan belajar untuk menemukan sendiri pelafalan yang benar terhadap kata berbahasa Inggris yang ingin dipelajarinya.

Penelitian ini sejalan dengan penelitian yang dilakukan oleh Darmiati (2012) [2] yang menyatakan bahwa $87 \%$ dari keseluruhan siswa yang ada di Taman Kanak-Kanak Padang meningkat pengembangan kosakata Bahasa Inggrisnya menggunakan permainan labeling. Peningkatan kemampuan kosakata Bahasa Inggris dirasa sangat penting menurut Rusefrinaria (2012) [3] yang menyimpulkan bahwa pengembangan kosakata bahasa Inggris anak usia dini sangat bagus dilaksanakan semenjak anak usia dini. Tubbs \& Moss (2005) [4] juga menyatakan:

"Speaking a second language has many benefits, such as communicating with people from various parts of the evershrinking world and developing a clearer understanding of the cultural perspectives of people from different backgrounds".
Hal tersebut berarti bahwa berbicara bahasa kedua memiliki manfaat sebagai alat komunikasi dengan orang-orang dari berbagai negara dan mengembangkan perspektif dari berbagai budaya dari berbagai latar belakang.

\section{METODE PENELITIAN}

Jenis penelitian ini adalah penelitian tindakan kelas dengan subjek penelitian anak-anak kelompok B PAUD Oasis Kids Kota Semarang tahun ajaran 2018/2019 berjumlah 7 anak, terdiri dari 5 anak perempuan dan 2 anak laki-laki. Teknik dan alat pengumpulan data adalah observasi, wawancara dan dokumentasi. Validasi penelitian menggunakan trianggulasi sumber, alat, dan metode. Penelitian ini dilaksanakan pada Semester I bulan Juli-Oktober 2018.

Peneliti sendiri merupakan pendidik yang telah lama mengajar di PAUD Oasis Kids, sehingga benarbenar mengetahui permasalahanpermasalahan yang terjadi di dalam kelas. Pada kondisi awal, kemampuan bahasa Inggris anak yang ada di dalam kelas masih terbilang cukup rendah. Penguasaan kosakata anak juga belum banyak. Hal ini tentunya merupakan suatu permasalahan yang harus segera di selesaikan agar kemampuan bahasa Inggris anak semakin meningkat.

\section{HASIL DAN PEMBAHASAN}

Hasil rekapitulasi observasi siklus I tentang kemampuan Bahasa Inggris anak setelah mengikuti kegiatan pembelajaran menggunakan media Baca Kata berbasis Android dengan materi menirukan kembali kosakata Bahasa Inggris, dapat diketahui bahwa hanya $21.43 \%$ anak kelompok B PAUD Oasis Kids Semarang tahun ajaran 2018/2019 
yang kemampuan Bahasa Inggrisnya dalam kriteria baik. Sedangkan $42.85 \%$ anak kelompok B PAUD Oasis Kids Semarang tahun ajaran 2018/2019 kemampuan Bahasa Inggrisnya berada pada kriteria cukup. Namun, masih ada 35,72\% anak kelompok B PAUD Oasis Kids yang kemampuan Bahasa Inggrisnya berada pada kriteria kurang. Hasil rekapitulasi siklus I ini telah mengalami peningkatan sebesar 7,15\% dibandingkan hasil observasi pra siklus. Peningkatan persentase kemampuan Bahasa Inggris anak pada kriteria baik ini belum memenuhi indikator kinerja yang ditargetkan, yaitu sebesar $75 \%$.

Hal ini juga diperkuat dengan kesimpulan dari hasil wawancara peneliti dengan salah satu pendidik PAUD Oasis Kids Semarang yang menyatakan bahwa rata-rata kemampuan Bahasa Inggris anak kelompok B PAUD Oasis Kids Semarang telah meningkat kemampuan Bahasa Inggrisnya. Namun, dalam hal membaca kosakata Bahasa Inggris dengan pelafalan yang tepat anak-anak kelompok B PAUD Oasis Kids masih membutuhkan bimbingan. Oleh karena itu, perlu dilakukan suatu upaya untuk meningkatkan kemampuan Bahasa Inggris anak kelompok B PAUD Oasis Semarang tahun ajaran 2018/2019 agar mencapai persentase sebesar $75 \%$ pada kriteria baik. Sehingga indikator kinerja yang mensyaratkan $75 \%$ kemampuan Bahasa Inggris anak meningkat setelah belajar Bahasa Inggris dengan menggunakan media Baca Kata berbasis android dengan materi menirukan kembali 4-5 urutan kata tanpa menggunakan media pendamping dengan kriteria kemampuan Bahasa Inggris baik, belum berhasil.

Refleksi berupa koreksi terhadap tindakan yang telah dilaksanakan ini dilakukan untuk mengetahui kekurangan yang ada pada siklus I. Berdasarkan hasil refleksi ditemukan bahwa aktivitas anak kelompok B PAUD Oasis Kids Semarang dalam mengikuti pembelajaran Bahasa Inggris dengan menggunakan media Baca Kata berbasis android belum maksimal. Anak-anak cenderung masih kesulitan untuk mengoperasikan media Baca Kata dan terlihat beberapa anak masih belum benar dalam melafalkan kosakata Bahasa Inggris. Anak-anak juga terlihat belum percaya diri untuk mengucapkan kosakata Bahasa Inggris tanpa bantuan media Baca Kata. Pada pertemuan pertama anakanak terlihat masih asing dengan media Baca kata yang diperkenalkan.

Pada pertemuan kedua, anakanak mulai dipersilakan untuk maju satu persatu mempraktikkan cara penggunaan media Baca Kata dengan bimbingan guru. Anak-anak juga terlihat masih kesulitan dalam mengetikkan kata pada tablet. Pada pertemuan ketiga terlihat ada beberapa anak yang telah lancar dalam menggunakan media Baca Kata dan ada juga anak yang masih sering salah mengetikkan kata.

Pada pertemuan keempat terlihat anak-anak yang sudah lancar menggunakan media Baca Kata membantu anak yang masih kesulitan dalam menggunakan media Baca Kata. Dalam menirukan kosakata yang dilafalkan oleh media Baca Kata juga terlihat beberapa anak ada yang masih keliru pelafalannya. Namun, anak yang pelafalannya sudah baik bersedia untuk memberikan contoh yang tepat kepada teman-temannya cara membaca kosakata Bahasa Inggris yang diajarkan. Anak-anak juga masih sering lupa dengan kosakata yang diajarkan pada hari sebelumnya. Ini menandakan bahwa belum semua anak mampu menghafalkan kosakata Bahasa Inggris dengan baik. Hal tersebut dapat dilihat dari analisis hasil siklus I setiap pertemuannya yang datanya terlampir. Hasil pada siklus I ini belum mencapai indikator 
keberhasilan dalam penelitian tindakan kelas ini. Indikator keberhasilan dalam penelitian ini yaitu sebesar $75 \%$ anak meningkat kemampuan Bahasa Inggrisnya setelah mengikuti proses pembelajaran menggunakan media Baca Kata berbasis android, yang ditandai dengan perolehan kriteria baik.

Hasil rekapitulasi observasi siklus II tentang kemampuan Bahasa Inggris setelah mengikuti kegiatan menggunakan media Baca Kata berbasis android dengan materi menirukan kosakata Bahasa Inggris dengan pelafalan yang tepat, dapat diketahui bahwa 75\% anak kelompok B PAUD Oasis Kids Semarang tahun ajaran 2018/2019 yang kemampuan Bahasa Inggrisnya dalam kriteria baik. Sedangkan hanya $25 \%$ anak kelompok B PAUD Oasis Kids Semarang tahun ajaran 2018/2019 kemampuan Bahasa Inggrisnya masih dalam kriteria cukup. Tidak ada anak kelompok B PAUD Oasis Kids Semarang tahun ajaran 2018/2019 yang kemampuan Bahasa Inggrisnya berada pada kriteria kurang. Hasil rekapitulasi siklus II ini telah mengalami peningkatan sebesar 53,57\% dibandingkan dengan hasil observasi siklus I. Peningkatan persentase kemampuan Bahasa Inggris anak pada kriteria baik ini telah memenuhi indikator kinerja yang ditargetkan, yaitu sebesar $75 \%$.

Hal ini juga diperkuat dengan kesimpulan dari hasil wawancara peneliti dengan salah satu pendidik PAUD Oasis Kids Semarang yang menyatakan bahwa anak kelompok B PAUD Oasis Kids Semarang telah mampu membaca kosakata Bahasa Inggris dengan pelafalan yang tepat. Anak-anak juga mampu memahami instruksi-instruksi sederhana dalam Bahasa Inggris dengan baik. Oleh karena itu, tidak perlu dilakukan suatu upaya untuk meningkatkan kemampuan Bahasa Inggris anak kelompok B PAUD Oasis Kids Semarang. Sehingga indikator kinerja yang mensyaratkan 75\% kemampuan Bahasa Inggris anak meningkat setelah mengikuti kegiatan pembelajaran Bahasa Inggris menggunakan media Baca Kata berbasis android dengan materi menirukan kembali kosakata Bahasa Inggris dengan media pendamping gambar poster dengan kriteria baik, telah berhasil.

Berdasarkan hasil penelitian pada siklus I dan II menunjukkan bahwa penggunaan media Baca Kata berbasis android dapat meningkatkan kemampuan Bahasa Inggris anak kelompok B PAUD Oasis Kids Semarang tahun ajaran 2013/2014. Hal ini terlihat dari pengamatan yang yang dilakukan oleh peneliti terhadap aktivitas anak yang kemampuan Bahasa Inggrisnya pada siklus II mengalami peningkatan dari siklus I. Kemampuan Bahasa Inggris anak pada siklus I masih tergolong cukup. Hal ini ditunjukkan dengan analisis hasil observasi siklus I di setiap pertemuan. Dari 4 pertemuan yang dilakukan di siklus I, menunjukkan bahwa pada keempat pertemuan tersebut kemampuan Bahasa Inggris anak kelompok B PAUD Oasis Kids Semarang tahun ajaran 2013/2014 dalam kriteria cukup.

Kemampuan Bahasa Inggris tersebut dapat dilihat dari kemampuan anak menghafal kosakata Bahasa Inggris, kemampuan anak memahami instruksi sederhana dalam Bahasa Inggris, kemampuan melafalkan kosakata Bahasa Inggris dengan tepat, dan kemampuan membaca kosakata Bahasa Inggris dengan tepat. Hasil rekapitulasi di siklus I secara umum kemampuan Bahasa Inggris anak pada kriteria baik sebesar 21,43\%. Sedangkan hasil rekapitulasi di siklus II secara umum, kemampuan Bahasa Inggris anak pada kriteria baik sebesar $75 \%$. 
Peningkatan kemampuan Bahasa Inggris anak kelompok B PAUD Oasis Kids Semarang dari pra siklus, siklus I, dan siklus II tersaji dalam tabel berikut ini:

Tabel 1. Perbandingan Rekapitulasi Hasil Observasi Pra Siklus, Siklus I dan Siklus II

\begin{tabular}{llccc}
\hline \multirow{2}{*}{ Indikator } & & \multicolumn{3}{c}{ Tingkat Keberhasilan } \\
& \multicolumn{1}{c}{$\begin{array}{c}\text { Nilai } \\
\text { Kemandirian }\end{array}$} & $\begin{array}{l}\text { Pra } \\
\text { Siklus }\end{array}$ & $\begin{array}{l}\text { Siklus } \\
\text { I }\end{array}$ & $\begin{array}{l}\text { Siklus } \\
\text { II }\end{array}$ \\
\hline $\begin{array}{l}\text { Meniru } \\
\text { kembali } 4-\end{array}$ & Baik & 14.28 & 21.43 & 75.00 \\
$\begin{array}{l}\text { 5 urutan } \\
\text { kata }\end{array}$ & Cukup & 28.57 & 42.85 & 25.00 \\
\hline \multicolumn{2}{c}{ Kurang } & 57.15 & 35.72 & 0 \\
\hline
\end{tabular}

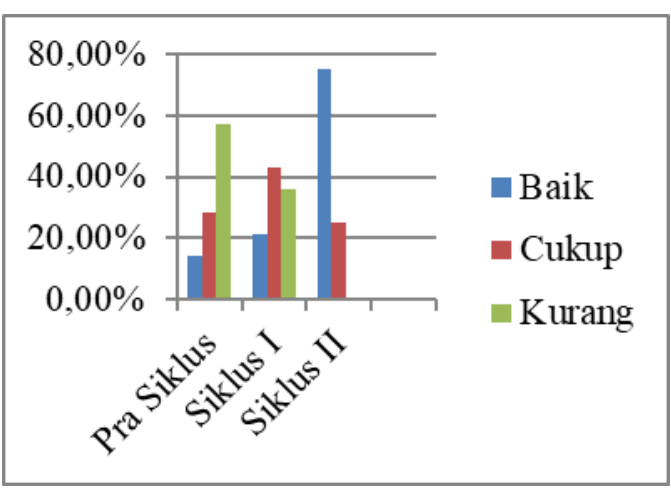

Gambar 1. Perbandingan Rekapitulasi Hasil Observasi Pra Siklus, Siklus I dan Siklus II

Berdasarkan hasil penelitian dapat disimpulkan bahwa hipotesis tindakan yang berbunyi melalui media Baca Kata berbasis android dapat meningkatkan kemampuan Bahasa Inggris anak kelompok B PAUD Oasis Kids National Pluss School Semarang tahun ajaran 2018/2019.

Hasil dari peneltian tindakan kelas ini membuktikan kebenaran teori yang dikemukakan oleh Suyanto (2007:101) [1] bahwa media dapat dimanfaatkan antara lain untuk membantu menyederhanakan proses pembelajaran bahasa dan menyempurnakannya, mengurangi penggunaan bahasa ibu atau bahasa pertama, membangkitkan motivasi atau minat belajar siswa, menjelaskan konsep baru agar siswa dapat memahami tanpa kesulitan dan salah pengertian, menyamakan persepsi, meningkatkan kualitas pembelajaran Bahasa Inggris dan membuat proses belajar lebih menarik dan interaktif. Hal ini karena media Baca Kata berbasis android telah diterima kebenarannya setelah dilakukan penelitian tindakan kelas dapat meningkatkan kemampuan Berbahasa Inggris anak kelompok B PAUD Oasis Kids Semarang tahun ajaran 2018/2019.

\section{SIMPULAN}

Berdasarkan hasil penelitian tindakan kelas dapat disimpulkan bahwa melalui media Baca Kata berbasis android terbukti dapat meningkatkan kemampuan berbahasa Inggris anak kelompok B PAUD Oasis Kids Semarang tahun ajaran 2018/2019. Hal tersebut ditandai dengan tercapainya indikator kinerja yaitu sebesar $75 \%$ kemampuan berbahasa Inggris anak kelompok B PAUD Oasis Kids Semarang tahun ajaran 2018/2019 terdapat pada kategori baik dalam lembar observasi.

Peningkatan kemampuan berbahasa Inggris anak kelompok B PAUD Oasis Kids semarang tahun ajaran 2018/2019 dapat dilihat dalam rekapitulasi lembar observasi yang menyatakan bahwa pada saat pra siklus kemampuan berbahasa Inggris anak pada kategori baik sebesar $14.28 \%$, kemudian pada siklus I meningkat menjadi $21.43 \%$, dan pada siklus II kemampuan berbahasa Inggris anak kelompok B PAUD Oasis Kids Semarang tahun ajaran 2018/2019 berada pada kategori baik sebesar $75 \%$. 


\section{DAFTAR PUSTAKA}

[1] Suyanto, K. (2007). English for Young Learners: Melejitkan potensi anak melalui english class yang fun, asyik, dan menarik. Jakarta: Bumi Aksara.

[2] Darmiati. (2012). Pengembangan Kosa Kata Bahasa Inggris Anak Usia Dini Labeling Benda-Benda Taman Kanak-Kanak Padang.

[3] Rusefrinaria. (2012). Peningkatan Bahasa Inggris anak melalui permainan tebak suara dengan kartu gambar binatang di PAUD Palapa I Kecamatan Batang Anai Kabupaten Padang Pariaman.

[4] Tubbs, S. L., \& Moss, S. (2005). Human communication: Kontekskonteks komunikasi. Bandung: Rosdakarya. 